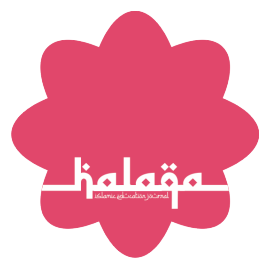

OPEN ACCESS

ISSN 2503-5045 (online) ISSN 1412-9302 (print)

Edited by: Musfiqon

Reviewed by: Jajang Aisyul Muzakki

*Correspondence: Mohd Burhan Norhapizah

nrizahuia@gmail.com

Received: 4 Januari 2020 Accepted: 29 Januari 2020 Published: 25 Oktober 2020

Citation:

Burhan Norhapizah M, Mahfuzah MZ, Mohamed A, Jusoh MKA and

Ayub MN (2020) Evaluating The

Quality of Blended Learning

Strategy Based Module for Islamic

Civilization and Asian Civilization

Course.

Halaqa. 4:2.

\section{Evaluating The Quality of Blended Learning Strategy Based Module for Islamic Civilization and Asian Civilization Course}

\section{Mengevaluasi Kualitas Modul Berbasis Strategi Pembelajaran Campuran untuk Peradaban Islam dan Kursus Peradaban Asia}

\author{
Mohd Burhan Norhapizah ${ }^{1 *}$, Mohamed Zabidi Mahfuzah ${ }^{1}$, Asjad Mohamed ${ }^{1}$, Mohd \\ Kamal Azman Jusoh ${ }^{1}$, Mohd Nasir Ayub ${ }^{2}$ \\ ${ }^{1}$ Academy of Contemporary, UiTM Cawangan Pahang (Kampus Pasir Gudang), Malaysia, ${ }^{2}$ UiTM Cawangan Kedah \\ (KampusMerbok), Academy of Contemporary Islamic Studies, Malysia
}

This study aimed to evaluate the digital learning content for Islamic Civilization and Asian Civilization (TITAS) course based on Blended Learning strategy at one of the public universities in Malaysia. This research adopted Type 1 developmental research design in which its formative evaluation phase involved an alpha and beta testing to elicit responses to the module. The instruments used were expert evaluation form, questionnaires, and the digital learning module prototype software. A total of nine (9) experts from public universities in Malaysia and fourty (40) undergraduate university students from Universiti Teknologi MARA took part as purposive sampling. The usability of the digital learning module was seen relative in terms of 'flexibility' and 'learning community' aspect which obtained the highest mean (mean $=5.00$ ) among experts. Whereas students had different perception on factor contributed to the students' usage of the digital learning module, which they equally found that 'flexibility' aspect obtained the highest mean (mean $=3.93$ ), followed by the aspect on 'personel learning' (mean $=3.90$ ) and 'complementary learning' (mean $=3.88$ ). In addition, content experts recommended aspect of values need to exert in the digital learning module, while technological and blended learning experts stated that the design, interactivity, guidelines and links required some improvements to produce a better module for TITAS. Overall, this study contributes to the development of blended university compulsory course for TITAS based on users' need.

Keywords: Evaluating, Blended Learning, Alpha Test, Beta Test, Islamic Civilization and Asian Civilization(TITAS), Module 


\section{INTRODUCTION}

As an effort to support the National Education Philosophy and the Islamic Education Philoso- phy, the TITAS Course was introduced as one of the compulsory university courses, which are a mandatory requirement for graduation for Malaysian students, offered to all students regard- less of course of study (general Studies Syllabus 2013). Looking at the fact that the Malaysian community is diversified in terms of religion, ethnicity and culture Bakar and Ahmad (2012) , 4 civilizations, which are the Islamic Civilization, the Malay Civilization, the Chinese Civiliza- tion and the Indian Civilization, were chosen for discussion. However, the younger generation is detached from ancient history due to the fact that most of the younger generation regard

history as unimportant. Thus, as the trend with life, traditional values, including religious val- ues are no longer respected, become dated and irrelevant in the current way of life Bakar and Ahmad (2012). Hence, the handling of the TITAS Course requires thorough planning so that the students attending the course can be well managed Bakar and Ahmad (2012). Based on the overall view, the mode of delivery for this course is similar in all IPT in Malaysia. It is conducted through lectures, small group discussions and presentations Burhan (2016). However, these students have basic expertise in technology and are ready to accept new skills. Studies by Mohd and Kosmo (2012) have found that $96.99 \%$ of studies prefer their lecturers use various methods of instruction.

According to respondents, repetitive method of instruction such as lecturing and power point presentations may cause students to become unmotivated, and bored. Furthermore, these findings are parallel with the findings of studies done by \&amp;ab. Halim and Tamuri (2013), in which, respondents feel that lecturers do not fully utilise the use of ICT and diversify methods of instruction. Respondents hope that different methods of instruction are employed, including the use of technology, so as to provide motivation, draw attention, relieve boredom and help to better understand the subject contents. Additionally, a study by Kamal and Kassim (2015) also presented that the use of ICT is an effective method of P\&P. Research on BL strategy based elec- tronic content development design as a part of compulsory university courses such as Islamic Education and Islamic Civilization, are still sparsely discussed. In agreement with Malaysian Education Development Plan 20132025 which has set 10 steps, whereby the 9th step of the education system refers to a global level online learning. Thereby, Blended Learning (BL) model becomes the main pedagogical approach in transforming this system at all IPTs (Ministry of Education Malaysia 2012). Therefore, the focus of this paper is to discuss the design and devel- opment of the TITAS module, based on BL strategy, and formative evaluation of the module.

\section{METHODOLOGY}

This research uses developmental research design. This is a pragmatic research, guided by the- ory and practices, based on orientation, focused on participants and collaborative, with the aim of practically testing and validating theories Patton (2002). Developmental research design was used to collect empirical data, which is used to assist the development of new theories that will contribute towards the good practices in designing instruction. Research on product manu- facturing and learning materials of this study are built based on type 1 development design as discussed by Richey et al. (2014). There are three phases of research; each phase having a partic- ular mode of study to solve the issue being analysed. In the context of this research, discussions will focus only on design phases and formative aspect of development Richey and Klein (2007), to get feedback on the usability of the digital learning module which has already been devel- oped. Sample choices are aimed so as to obtain rich data needed for this study Bloomberg and Volpe (2008) which will facilitate in the understanding of the phenomena under investigation. In this phase, 9 experts were elected to review and evaluate the validity of the BL strategy based, digital learning content of the TITAS course module.

The experts were chosen to represent various backgrounds and experiences on the phenomenon which is the focus of this study. After being evaluated by a group of external experts, the module is then evaluated by the users. The evaluation of small groups or the study of the experimental prototype module is administered to two groups of students, comprising of 20 students in a group. The students are currently studying at a certain UiTM. This group of students have a lot in common with the participants of the actual study, in terms of academic achievements, socio-economic status and field of study. Evaluation by students is undertaken to complement the data evaluation performed by the panel of experts Weston (1987). This campus was chosen due to the fact that the lecturers of Academy of Contemporary Islamic Studies (ACIS) are will- ing to use the said model. Classes were chosen according to these criteria; (1) varying student achievements (high, moder- ate, low); (2) various background of expertise; and (3) a multi- tude of knowledge background Dick et al. (2005).

\section{RESULTS AND DISCUSSION}

In the design and development phase, at least two main tests are involved. Alpha tests are con- ducted by the design and development group, comprising of experts in the fields concerned. Next, beta tests are performed by users.

\section{Alpha Test}

The results of the study indicate that items 'feedback' (mean $=5.0)$, 'anytime' (mean $=5.0)$, 'com- municate with friends' $($ mean $=5.0)$, 'unlimited' $($ mean $=5.0)$, flexible' $($ mean $=5.0)$, 
'interact online' $($ mean $=5.0)$, 'interact with lecturers' $($ mean $=$ 5.0), obtained the highest mean value. Apart from that, items 'interactive notes' $($ mean $=4.67)$, 'module content' $($ mean $=$ 4.67 ), 'share materials' (mean $=4.67)$, 'quiz marks' (mean $=$ 4.67 ) and 'assisted' (mean $=4.67$ ) obtained mean values of almost the highest. Subsequently, ),items 'activities'(mean = $5 \mathrm{~min}$ ), 'design' (mean $=4.33$ ), 'various methods of learning' $($ mean $=4.33)$, 'share ideas' (mean $=4.33)$, 'record of participation' (mean $=4.33)$, 'according to ability' (mean $=4.33$ ), 'choose' $($ mean $=4.33)$ and 'support learning' $($ mean $=4.33)$ are at a lower scale on the high level mean. Items 'server' (mean = 4.00 ), 'learning enjoyment' (mean $=4.00$ ) and 'improve understanding' (mean $=4.00$ ) are at the min- imum scale for high level mean. Hence, items that did not achieve the highest value still have to be refined; to ensure that these items can be well implemented in the learning of BL strat- egy based Islamic Civilization Course. Table 1 exhibits BL alpha tests for the execution of BL strategy based module.Table 1

\section{[Table 1 about here.]}

Based on the results of the Alpha Test performed, e-CITAC module can be used because all the experts are in high agreement $(<$ mean 4.00) towards all items in the test. Apart from that, the value of the believability coefficient is more than 0.80 . However, several aspects need to be improved in order to impart better outcome in students' learning. Taking into account the mod- ule's betterment form, which is attached together with the survey, these are the improvements proposed by experts in the Table 2 .

\section{[Table 2 about here.]}

\section{Beta Test}

The beta test was conducted after experts have put its module through the alpha test. Therefore, the beta test is the final phase of testing using sample group users before the module is dis- tributed to actual users and its usability evaluated. The beta test was administered on a group of 40 students, currently pursuing Bachelor degrees in Clustered Science and Technology, who are taking the TITAS Course at UiTM. Table 3 shows the results obtained from the beta test, which looked at the implementation aspect of the BL strategy based TITAS Course module. Based on the findings, students generally consider that the e-CITAC module is at a moderately high level for use in the TITAS Course. Although the e-CITAC model can be utilised, none of its item are the highest level. Subsequently, the module's BL elements have to be improved so as to make it suitable for implementation using the BL strategy. Therefore, more attention and refinement have to be given to items such as 'unlimited time' (mean $=3.48)$ and 'server' (mean $=3.43$ ) which obtained the minimum scale on the moderately high level.' This, in turn, will enhance the quality of learning and $\mathrm{BL}$ strategy based learning.
[Table 3 about here.]

This research indicated that the e-CITAC module developed is able to meet the needs of UiTM students, who are pursuing Bachelor Degrees, in learning the TITAS Course. Research results obtained show that the e-CITAC module, which is built based on BL strategy, received pos- itive feedback from both experts and students. Furthermore, the results also show that the

research main concept, which was infused with learning theories, BL principle, ARCS moti- vational model, multimedia elements, is able to leave a positive impact on the students. Stu- dents are more motivated to study the TITAS Course when the BL strategy is integrated into the development of the e-CITAC module. This is due to the availability of varying methods of instruction, learning environment, media and tasks which changes the learning pattern from passive to active learning Bernard et al. (2014). Results obtained from the quantitative study of the e-CITAC module shows that the module is able to help students in learning the TITAS Course, especially in the area of personal learning. The e-CITAC model, which was designed and constructed based on the BL strategy, enables the students to pick and choose learning materials and tools that are suitable for their needs Dean et al. (2001). Moreover, students' learning can be fortified through a multitude of strategies such as method of instruction, mode of delivery, media and tasks provided in BL.

According to Bernard et al. (2014), BL is a priceless learning experience because it offers an interfusion of pedagogical techniques, modes of delivery, students' participation strategies, technologies and modalities Singh (2003). There are certain components in the BL approach that are different, compatible and able to contribute immensely towards the students' success. Kamal and Kassim (2015), in his study, concluded that a combination of various teaching and learning methods is an effective teaching method for Islamic Civilization Course. Integrating learning and teaching methods such as lectures, discussions, slideshows and student centred learning creates a better teaching method.

Additionally, delivering theoretical knowledge about education through the use of diverse methods of instruction can alleviate students' boredom Zhao and Yang (2011). Students are given the opportunity to arrange their own time, place, schedule and evaluation of learning depending on their own characteristics, interests and style of learning Huang (2012). However, a study conducted by T Terrell and Dringus (2000) has discovered that learning online, regardless of the student's style of learning, contributes to the student's success. Learning online requires that the students exercise extremely high level of self discipline and the lecturers provide a compre- hensive guide for arranging and choosing learning materials online Curtis and Graham (2006). In addition, students need to get sufficient exposure to innovations involving technologies and skills in order to improve and maximise the results of learning Thang et al. (2013). Even though is of the opinion that technological 
skills are irrelevant in the involvement of students in a BL environment, differing student needs and contact with lecturers online are factors that need to be considered. Hence, in BL, the style of learning is not the only determining factor in the success of online learning. Learning approach and learning control Curtis and Graham (2006), and personal online access also need to be taken into account. Horn and Staker (2011) admit that teachers are the main contributors towards the success of the BL environment. This view is supported by Barkley (2010) who sees that the effectiveness of lecturers in handling learning is an important factor contributing to the success of BL. These findings are totally contrary to the opinion of, who perceive that students with varying levels of academic achievements show sig- nificant improvements in their academic achievements when the educators' approach is suited to the students' learning style. In reality, in BL, the success of a course does not solely depend on learning style.

On the contrary, in this study, personal learning is of interest to students because not only are they given the opportunity to learn according to their individual styles, they are given more than that. The prophet Rasulullah S.A.W. also took into consideration each student's individual differences. His conduct towards his Companions was clearly determined by their willingness, skills, characteristics and the differing environment of the students (An-Nawawi 1983). Through the use of BL, students are given the chance to learn using a myriad of approaches and learning objects, anytime and anywhere, under their own control and by being continuously guided by their lecturers to manage and implement online learning. Thus, research findings also show that the e-CITAC module complements the learning of the TITAS Course because it provides various forms of support materials which can be used in learning. This module is equipped with various types of study notes, online activities, field activities, video production projects, construction of blogs or writing paper work, and interactive quizzes. A learning environment which is equipped with various modalities is beneficial for students because they are involved with collaborative tasks in and outside of lectures.

Moreover, the implementation plan of BL provided to lecturers and students is as a guide to ensure that the targeted results of learning are achieved. This finding is in line with the B-R- G map model where opined that three components are needed to design technology based BL in learning; the components being content design, design of activities and technology design. Bloom's Taxonomy is used to represent the learning objective contained in the course content. Meanwhile, Redeker's Taxonomy is utilised to classify components of activities and Guerra Scale is used to determine the most suitable tools and technology for learning. However, discovered that the combination of technology and content does not necessarily give rise to effective learn- ing. On the other hand, a systematic design process is essential in the development of $\mathrm{BL}$ strategy based courses. This corresponds with the stance. To produce effective learning, four instruc- tion phases comprising the display of information, student's guide, practical and evaluation have to be included in the learning session. Since the e-CITAC module is arranged systemati- cally, guided by the instruction design and contains a multitude of supporting materials which are geared towards users' needs, then, it is only fitting that a majority of students feel that the module is able to complement the existing learning content.

This study also found that the e-CITAC module can be fully employed in the learning of the TITAS Course. This is due to the fact that its diverse contents, consisting of study notes, learning activities, evaluation and guide provided are useful, complete and suitable. According to Picciano (2009), content is one of the principal driving force in instruction and it can be delivered using miscellaneous techniques. The content form of subjects pertaining to human- ity such as history and literature can be enhanced with the use of digital images. A study done by Ling et al. (2010) had exhibited that comprehensive notes, tutorial questions and course con- tents that are readily available and can be downloaded and printed anytime are able to excite students' interest. The view of Nur (1989) is applicable in this context, whereby educators in the field of Islamic Studies ought to consider, in depth, issues regarding ontology, epistemology and axiology. These is owing to the fact that these issues form the foundation of learning in tra- ditional religious learning systems and subsequently, have to be integrated with aqli knowledge such as history, mathematics, arts, etcetera so that students do not become bored with the hack- neyed approach. Accordingly, the use of ICT and social networks in Islamic Studies should not be frowned upon by the Muslim community in Malaysia because these modern approaches are able to provide a platform for delivering messages quickly and easily. Admittedly, Islam does not disallow its followers to use any method or approach in teaching and learning including the optimal use of present-day technology as long as its use is not contradictory to the rules and laws of Islamic sharia.

Therefore, integrating ICT technology in TITAS Course learning will illicit students' interest with the application of technology and diversity provided in online learning. This is in agree- ment with Jamaludin (2005) who believes that ICT assisted learning such as multimedia edu- cation and webbased learning are techniques employed during the 21st millennium. Apart from that, due to the flexibility of the e-CITAC module, it can be adapted to suit the time and place. Therefore, students react positively towards the e-CITAC module. These findings are in line with the aspiration of the Ministry of Higher Education, which advocates the use of flex- ible education, that is to say that education can be accessed anytime and anywhere (Ministry of Higher Education Malaysia 2016). Stated that BL environment is more beneficial than tra- ditional learning because of its accessibility and flexibility. Vignare (2006) is also in agreement with Osguthorpe and Graham. He asserted that flexibility can impart a dominant positive reac- tion on students in the learning process. Arbaugh and Duray (2002) also concur with both opin- ions and state that satisfaction towards the system and curriculum is influenced by the flexibility of the courses. 
Likewise, video production projects and blog construction, undertaken by students, give the students satisfaction because they are able to share the product of their group projects with their friends online. Additionally, learning through the doing projects, in itself, helps students to better understand the content of lessons by self experience and execution. With this method, students will undertake learning activities with complete interest and focus in a real-life situa- tion to achieve the desired result. This method is slightly different from the BL principle, where

online learning is widely available for topics relating to authentic assignment design added that virtual classes provide the main learning environment, if online discussions and face to face dis- cussion summaries and assignments are posted online. This creates cohesion between learning content and online learning process. Moreover, online discussion activities have received posi- tive response from students because they are able to share their ideas with friends. Results from previous studies show that students give a high value to active online learning component, such as group discussions and group assignments. Consequently, are able to build knowledge and compete positively in contributing ideas and opinions. Computer display in the form of virtual 3D (three dimension) stimulates the users' senses and feelings, creating the feeling of being at a location and interacting in various $3 \mathrm{D}$ environments. 3D environment creates, for students, a more meaningful and realistic learning experience and generates opportunity for them to think about the courses being studied. Fur-

\section{REFERENCES}

Arbaugh, J. B. and Duray, R. (2002). Technological and Struc- tural Characteristics, Student Learning and Satisfaction With Web-Based Courses an Exploratory Study of twoon- line MBA Programs. vol. 33, In Modul Pengajian Tamadun Islam dan Tamadun Asia, eds. Bakar, O., Ahmad, and A. B. Z. (Pener), 331-347.

Barkley, B. W. (2010).

Bernard, R. M., Borokhovski, E., Schmid, R. F., Tamim, R. M., and Abrami, P. C. (2014). A meta-analysis of blended learning and technology use in higher education: from the general to the applied. Journal of Computing in Higher Education 26, 87-122. doi: 10.1007/s12528-013-9077-3.

Bloomberg, L. D. and Volpe, M. (2008). Completing Your Qualitative Dissertation a Road Map From Beginning to End (Los Angeles: Sage Publications).

Burhan, N. M. (2016). Pembangunan dan Penilaian Modul Kursus Tamadun Islam dan Tamadun Asia (e-CITAC) Berasaskan Strategi Blended Learning. Tesis Ijazah Dr. Fal. Fakulti Pendidikan.

Curtis, J. B. and Graham, C. R. (2006)

Dean, P., Stahl, M., Sylwester, D., and J (2001). Effectiveness of Combined Delivery Modalities for Distance Learning and Resident Learning. Quarterly Review of Distance Education 2, 247-254.

Halim, N. M. B. and Tamuri (2013). Persepsi Pela- jar Terhadap Kaedah Pengajaran Pensyarah dalam Pen- didikan Islam: Pendekatan Blended Learning (BL) sebagai Suatu Alternatif. Kertas Kerja International Conferenceon Islamic Educatiion (ICIED, 6-07.

Horn, M. and Staker, H. (2011). The Rise of Blended Learn- ing (Mountainview, CA).

Huang, L. N. (2012). Practical Teaching Design of Basis of College Computer Engineering Based on Blended Learn- ing Model. Journal of Advanced Technology in Teaching 163, 119-123.

Jamaludin, R. (2005). Multimedia Dalam Pendidikan (Kuala Lumpur: Utusan Publications \& Distributors Sdn. Bhd). thermore, 3D environment gives significant benefits, which is not limited only to acquiring knowledge but also involves behaviour and motivation.

\section{CONCLUSION}

The TITAS Course module (e-CITAC) was designed and developed based on the concept frame- work and design model and the e-CITAC development module which is suited to users' needs. Meanwhile the theoretical framework in the module study advocates the use of BL strategy based learning and creating an active learning environment through the use of motivational ARCS learning model, multimedia learning environment, multimedia cognitive learning the- ory, BL learning principle and social constructivism learning theory. Current technological advances have transformed today's students' learning environment, making it different from the learning environment a century ago. Lecturer centreed learning has shifted to student cen- treed learning, where the students themselves build their own knowledge through what was learned, and the lecturers act as facilitators. Additionally, the teaching approach needs to be geared towards the interests and diverse characteristics of students, who are the main clients in the lecture hall. Therefore, the BL strategy which combines various methods of instructions, learning environment, mode of delivery, media and roles, is seen as able to contribute and rein- vigorate the learning pattern in the field of Islamic Studies today.

Kamal, M. and Kassim, A. (2015). Pelaksanaan Penga- jaran dan, di Institut Pendidikan Guru Malaysia di Lembah Klang: Kajian Kaedah dan Keberkesanannya. Tesis Dr. Fal. Akademi Pengajian Islam, P. T. I. (ed.).

Mohd, W. Z. W. H. and Kosmo, A. (2012), dengan Minat Pelajar, K. K. P. B. K. T. I. T. A. S. K., Halim, L., D., Chang, , Basri, et al. (eds.) (Bangi), 144-154.

Nur, M. M. (1989).

Patton, M. Q. (2002). Blending with Purpose: The Multimodal, ThousandOaks, ., Sage, and C. (eds.) (Picciano, A).

Richey, R. C. and Klein (2007).

Richey, R. C., Klein, Dlm, Spector, J. M., and Merill, M. (2014). Design and development research (Springer).

Singh, H. (2003). Building Effective Blended Learning Pro- grams. Journal of Educational Technology 43, 51-54.

Terrell, S. R. and Dringus, L. (2000). An Investigation of the Effect of Learning Style on Student Success in an Online Learning Environment. Journal of Educational Technology Systems 28, 231-238. doi: 10.2190/r53m-bvbd-ugv5-77eh.

Thang, S. M., Mustaffa, R., Wong, F. F., Noor, N. M., Mahmud, N., Latif, H., et al. (2013). A Quantitative Inquiry into the Effects of Blended Learning on English Language Learning: The Case of Malaysian Undergraduates. International Education Studies 6, 1-7. doi: 10.5539/ies.v6n6p1.

Vignare, K. (2006). Longitudinal Success Measures of Online Learning Students at The Rochester Institute of Technol- ogy. Elements of Quality Online Education: Practice and.

Zhao, D. and Yang, Q. (2011). Blended Learning Model Applied in College Teacher Education Case Study on Qual- ity Course of "Education" in Huazhong Normal Uni- versity. Kertas Kerja International Conferenceon e- Education, Entertainmentand e-Management, 27-29.

Conflict of Interest Statement: The authors declare that the research was conducted in the absence of any commercial or financial relationships that could be construed as a potential conflict of interest. 
Copyright $\odot 2020$ Burhan Norhapizah, Mahfuzah, Mohamed, Jusoh and Ayub. This is an open-access article distributed under the terms of the Creative Commons Attribution License (CC BY). The use, distribution or reproduction in other forums is permitted, provided the original author(s) and the copyright owner(s) are credited and that the original publication in this journal is cited, in accordance with accepted academic practice. No use, distribution or reproduction is permitted which does not comply with these terms. 


\section{LIST OF TABLES}

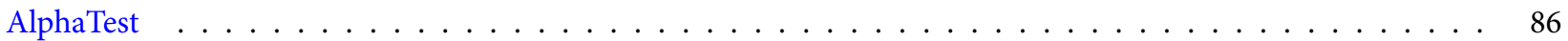

Experts'summaryon TITAS CourseModule . . . . . . . . . . . . . . . . . . . . . 8 87

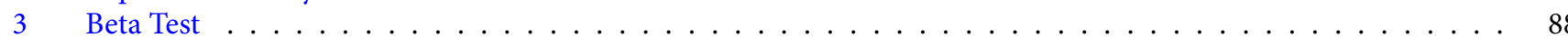


TABLE 1 | AlphaTest

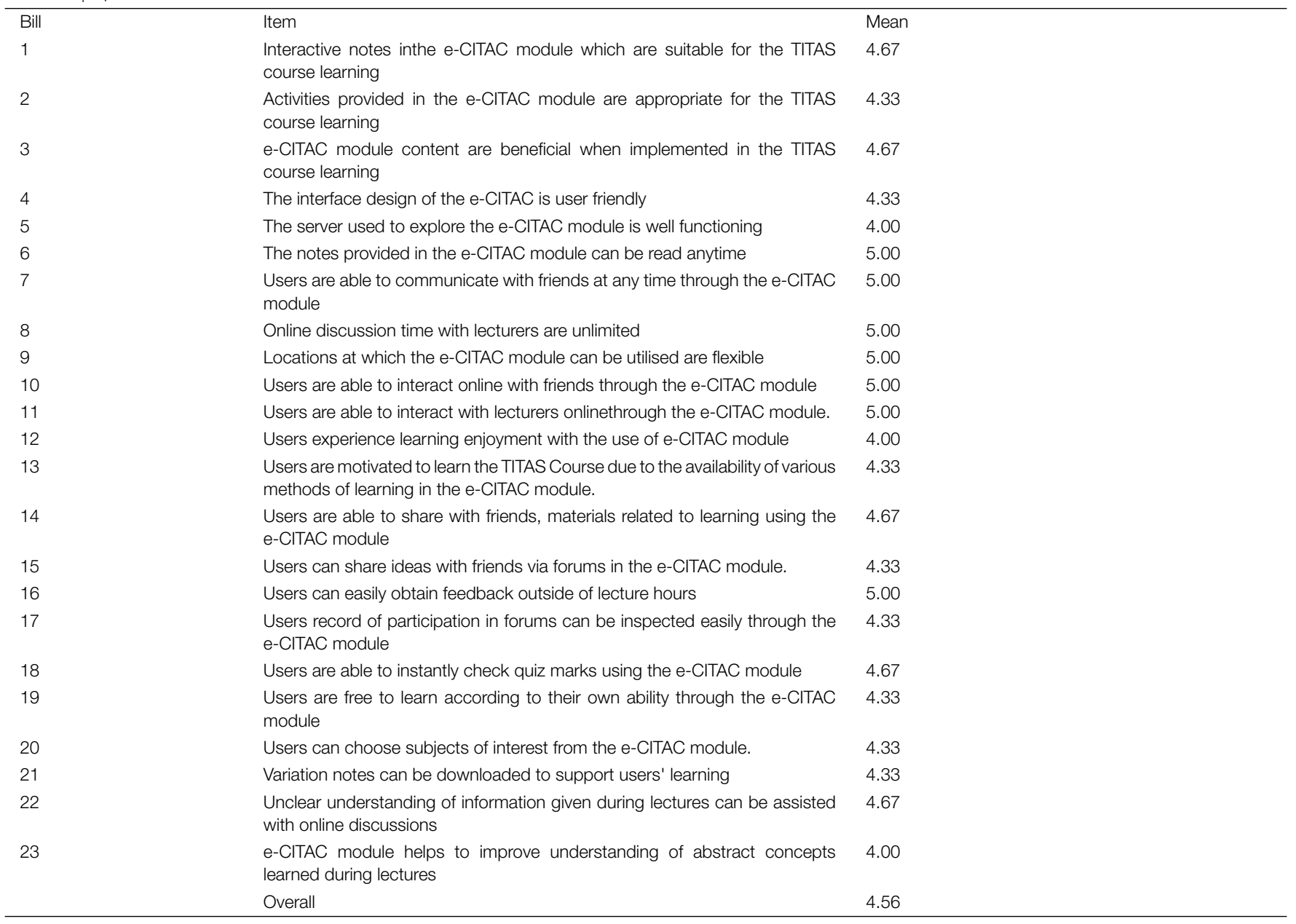


TABLE 2 | Experts' summaryon TITAS CourseModule

Expert categories Positive aspects

Expert 1

Expert 2

Expert 3 lead to
-Module content is very useful and complete.

-This model can clearly support BL

-Peripheral elements such as prayer times, al-

Quran verses and such, can created a more meaningful learning environment

- Materials can downloaded and shared

-Easy to navigate around

-Users have a clear idea of where each link will

-fulfills the learning styles of target students, the Gen Ys \& alphas.

-Module content is made available in buffet form which gives variation and flexibility to students especially adult students.

-Fulfills 24 hours a day and 7 days a week access criteria
Aspects that need to be improved

Interactive elements have to be improved (students only read texts and listen to music)

Shorten video (chunks)

Module design has to be improved in order to attract students' attention. The design of the main interface is dull. Results of learning have to be displayed clearly.

Graphics on interactive notes have to be simplified so they can be accessed quickly and easily

Interface design need to be improved so as to be more appealing
Challenges faced

Instructions in quizzes have to be amended and increased (arranged according to priority).

Links to forum with experts in the field of Islamic Civilization

Unable to rectify answers to quizzes after clicking the submit button

Guide cannot be accessed

Slow downloading of interactive notes even though site is accessed using high speed internet connection 
TABLE 3 | Beta Test

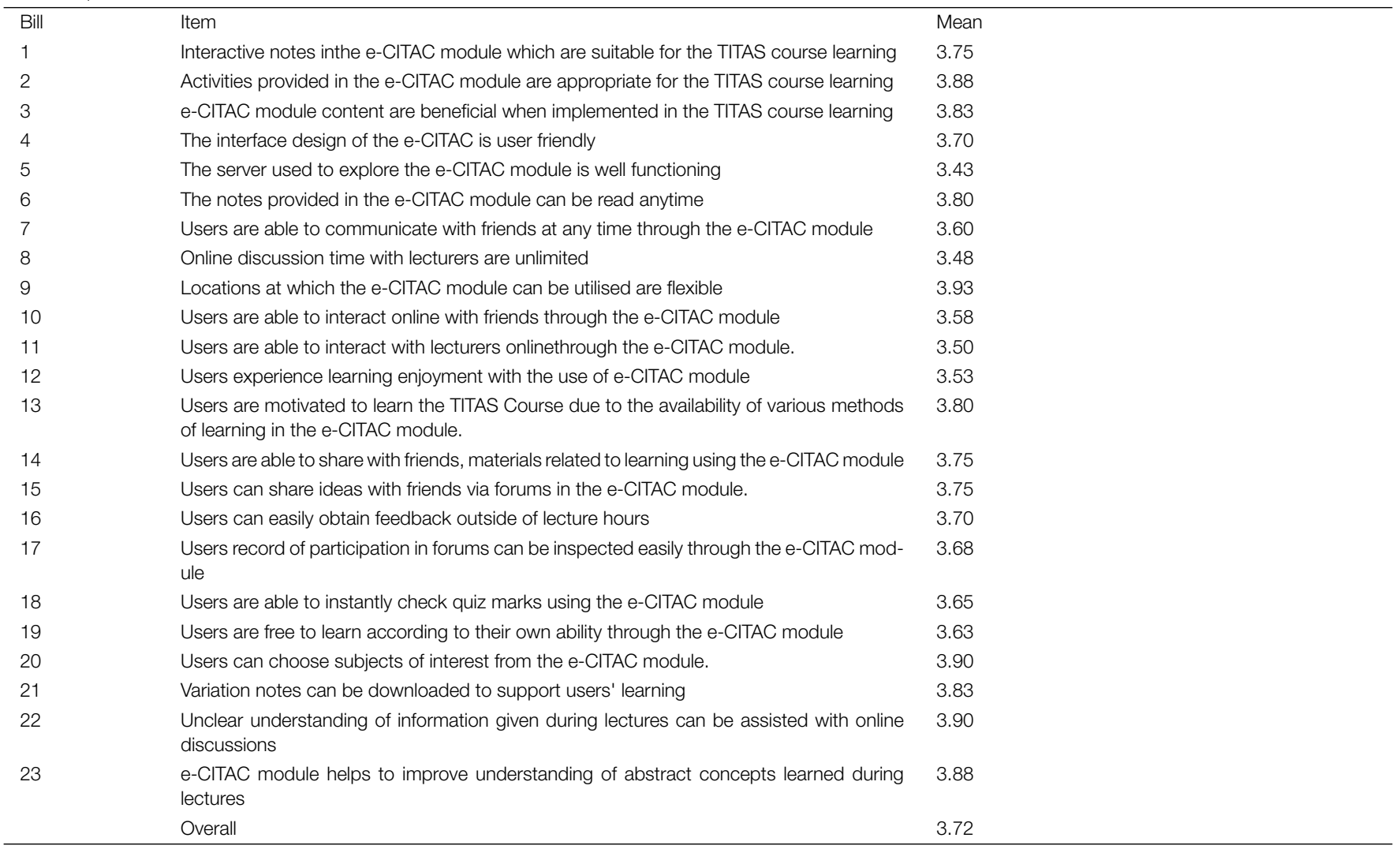

